\title{
From pitch to ditch: The client/ad agency life cycle
}

\author{
Sarah Turnbull \\ University of Portsmouth
}

\author{
Portsmouth Business School \\ University of Portsmouth \\ Richmond Building \\ Portland Street \\ Portsmouth PO1 3DE \\ United Kingdom
}

Tel: +44(0)239284 4701

Email: sarah.turnbull@port.ac.uk 


\begin{abstract}
While the partnership between an advertising agency and its client has often been referred to as a 'marriage' because of its closeness and longevity, it is now more realistic to expect relationships to last less than 3 years. The shorter nature of client/ad agency relationships reflects the changing nature of the marketing communication environment and the increasing focus on return-on-investment from communications activity. In addition to changes in the length of the relationship recent studies have identified the presence of new stages within the client/ad agency that have not previously been accounted for in the life cycle literature. Hence current frameworks of the client/ad agency life cycle need to be revisited to better reflect what stages exist. The paper draws on evidence from the literature and insights from the industry press and reports to suggest a new client/ad agency life cycle framework for discussion and further examination.
\end{abstract}

Keywords: Advertising, client/ad agency relationships, life cycle stages, Pitch, Chemistry Meetings, Tissue Sessions

\title{
Biography
}

Sarah Turnbull is a Fellow of The Chartered Institute of Marketing and a Senior Lecturer at the University of Portsmouth. Before joining the university Sarah spent 15 years working as a practitioner in advertising agencies both in London and Dubai. Her Middle East experience includes managing a number of prestigious government accounts including Emirates, Dubai Ports Authority and Dubai World Trade Centre.

Her main research interest is in advertising and the advertising creative development process. She has published a number of studies on the advertising industry in the UK and the Middle East in international journals. In addition she has contributed to industry publications and has a number of book contributions on advertising and brand communication. She has also written on Islamic marketing. 


\section{Introduction}

Advertising agencies operate in a highly competitive and volatile environment. Independent agencies compete for business against large global holding groups. The evolution of digital channels has led to increasing fragmentation of the media. Consumers have become sophisticated and demanding and ever harder to reach. It is not surprising that within this complex landscape agencies are finding it challenging to manage their relationships with clients. This paper explores the changing nature of these relationships and suggests existing frameworks that explain the relationship life cycle need to be revisited.

Client/ad agency relationships have attracted significant interest in the literature over the last three decades (Fam \& Waller, 2008; Henke, 1995; Turnbull \& Wheeler, 2014; Wackman, Salmon \& Salmon, 1986). One reason for this has been that the relationship between an advertising agency and its client is seen to be close and personal and social bonds form between parties (Fam \& Waller, 2008). This has provided a rich research environment for exploring the nature of inter-organisational relationships and has attracted a plethora of studies.

Over the last decade there has been an increasing interest in the role of the client/ad agency relationship on advertising outputs (Gambetti, Biraghi, Schultz, \& Graffigna, 2015; Koslow, Sasser \& Riordan, 2006). Given the intense nature of the advertising creative process it is not surprising that the relationship between the client and agency plays such a central role (Turnbull \& Wheeler, 2015). The increasing focus in the literature on the impact of the client/ad agency relationship on creativity reflects the industry acknowledgement of the significance of creativity (Shaw, 2014).

In the past some client/ad agency relationships have been known to last a significant length of time. Spanier (2010) provides examples such as Abbott Mead Vickers (AMV) and 
Sainsbury's as well as DDB and Volkswagen whose relationships together lasted over 30 years. In other cases such as JWT and Unilever the relationship has lasted over a century (Day, 2002). The industry press also reports how ex-Foote, Cone and Belding agency staff recount how the agency was so proud of the longevity of their client relationships that they carved their client's names in marble and displayed this at the agency's entrance (Turnbull, 2014). Such long relationships have led in the past to marriage analogies being used to describe the nature of client/ad agency relationships (Durkin \& Lawlor, 2001).

Despite such examples of long-lasting relationships however recent industry reports suggest that the average length of relationships between clients and agencies is shortening (Turnbull, 2014). Industry sources suggest the lifetime of client/ad agency relationships is now less than 3 years (ISBA, 2013). This short life cycle is disappointing considering the high switching costs for both client and agency (Davies \& Prince, 2010: Kulkarni, Vora, \& Brown, 2003). In particular the IPA (2014) identifies the high cost of the pitch process and suggests this costs larger agencies up to $£ 178,000$ a year and a total of 99 days in labour. Similarly the cost to clients is large as it is seen to take 6 months to settle into a working relationship with a new agency (IPA, 2014).

The changing nature of client/ad agency relationships has not been recognised in existing life cycle frameworks presented in the literature. Prior frameworks of the agency life cycle have been based on long term relationships and do not reflect our current knowledge of the exchange which takes place between clients and their advertising agencies. This paper seeks to redress this gap and discusses how recent knowledge gained from both empirical evidence and industry insights allows us to revisit the client/ad agency life cycle framework.

The paper begins with a review of the current client/ad agency life cycle frameworks and examines our existing knowledge of how relationships develop between clients and agencies. Next the paper discusses each of the client/ad agency stages that are suggested; 
Pre-relationship, Early relationship, Transition, Development and Maintenance, Dissatisfaction and Exit from current agreement. A revised framework is offered for discussion and future examination. The paper concludes with a discussion of areas for future research.

\section{Existing client/ad agency life cycle frameworks}

The organisational literature recognises that relationships between firms develop through a series of stages (Dwyer, Schurr \& Oh, 1987; Ford, 1980; Grönroos, 1980; Johanson \& Mattsson, 1987; Wilson, 1995). The frameworks offered to explain relationship development suggest that the relationship process is a linear one and organisations move through a sequence of stages as the relationship forms. Similarly, the advertising literature explains client/ad agency relationships developing in linear fashion and numerous life cycle frameworks have been proposed in the literature (Davidson \& Kapelianis, 1996; Fam \& Waller, 2008; Wackman et al, 1986; Waller, 2004). See Table 1. 
Table 1. Client/ad agency life cycle frameworks (1986-2008)

Author

Wackman, Salmon

\& Salmon (1986)

Davidson \&

Kapelianis (1996)

Halinen (1996)

Waller (2004)

Fam \& Waller

(2008)

\section{Framework \\ Stages in client/ad agency relationship development}

The agency-client life cycle

- Pre-relationship

- Development

- Maintenance

- Termination

- Pre-contracting

- Contracting

- Post-contracting theory model

- Pre-relationship

- Initial

- Growth

- Decline

- Constant

- Troubled

- Termination

- Evaluation/selection

- Relationship development \& maintenance

- Review/termination

- Inception

- Development

- Maintenance

- Termination

Wackman, Salmon and Salmon (1986) offer one of the earliest client/ad agency frameworks which suggest a 4-stage process beginning with a Pre-relationship stage, through Development, Maintenance and finally, Termination. Similarly, Davidson and Kapelianis (1996) suggest a 'pre' and 'post' stage in the relationship with a middle stage of Contracting where the relationship is seen to be active. Their Tripartite organisational model identifies only 3 stages within the life cycle however. In contrast, Halinen's (1996) study highlights a 7stage process which extends the stages of the relationship. Her relationship development 
phases identify that following a Pre-relationship, initial and growth phase the relationship enters stages of Decline, Constant, Troubled and finally a Termination stage. While extending the end stages of the relationship the framework reflects prior models that conclude with Termination. Waller (2004) suggests the Account management life cycle should be seen in 3 stages which include; Evaluation/selection, Relationship development and Maintenance followed by Review/Termination. More recently, Fam and Waller's (2008) 4 stage Agency-client life cycle framework divides the stages of Development and termination into individual phases within their framework.

Most client/ad agency relationship frameworks are therefore seen to include a prerelationship stage, development and maintenance, and termination stage. All suggest a stage where the relationship between the client and the agency has ended. Since the industry press suggests that clients are often known to maintain relationships with agencies and invite them to pitch for business in the future this aspect of the client/ad agency lifecycle needs to be revisited (Anon, 2014). Furthermore, the existing linear frameworks do not reflect the complexity of the stages, especially the pre-relationship stage where recent studies and industry reports suggest that in practice additional stages of relationship development are used. The literature for example provides evidence of Chemistry Meetings and Tissue Sessions (Turnbull and Wheeler, 2015). Similarly industry reports highlight the increasing importance attributed to the Transition stage of the relationship between the client and agency and in particular the first 100 days of the client/ad agency relationship (IPA, 2014). Current life cycle frameworks do not capture this knowledge.

This paper explores the recent findings from the literature and combines this evidence with industry reports to offer a revised client/ad agency life cycle framework that is seen to more accurately reflect current practice within industry and allow researchers to identify new avenues for future research. 


\section{Understanding client/ad agency relationship stages}

To gain a better understanding of client/ad agency relationships we explore each of the relationship stages; Pre-relationship, Early relationship, Transition, Development and Maintenance, Dissatisfaction and Exit from current agreement. Each stage is discussed in turn with a brief review of the literature on each.

Pre-relationship stage

While several life cycle frameworks acknowledge the existence of a pre-relationship stage (Davidson \& Kapelianis, 1996; Wackman et al, 1986; Halinen,1996) we have less understanding about the nature of this stage in the client/ad agency relationship.

The existing literature on the pre-relationship stage has focussed largely on the criteria used for selecting an agency (Turnbull \& Wheeler, 2014). Studies identify that clients seek agencies that offer good creative skill (Fam \& Waller, 2008; Jansen van Rensburg, Venter \& Strydom, 2010) and have good quality people (Fam \& Waller, 1999, 2008; Na, Marshall, and Son, 2003; Palihawadana \& Barnes, 2005). The literature also highlights the importance of cost (Jansen van Rensburg et al, 2010), previous category experience (Palihawadana \& Barnes, 2005), network and strategic capability (Turnbull \& Wheeler, 2014).

Despite a plethora of studies that have examined the selection criteria (for a full review see Turnbull and Wheeler, 2014), we have less knowledge regarding the selection process itself and the nature of the relationship between the client and the agency during this stage. 
Moeran (2005) does provide some insight into the selection process in Japanese agencies and explores the nature of this early stage relationship development between client and agency. His ethnographic study allows us a rare window into the world of advertising agency new business practice at the very early stages of client/ad agency relationship building.

In addition, Turnbull and Wheeler (2015) identify the stages that occur within the advertising creative process when the advertising is for a new business client. Their study suggests that the agency and client meets for a Chemistry Meeting to discuss the communications brief and develop the client/ad agency relationship in the pre-relationship stage (Turnbull \& Wheeler, 2015). These studies and industry papers identify that the pre-relationship stage between clients and their agencies is a complex one with many separate meetings taking place before the final pitch presentation.

In particular the identification in Turnbull and Wheeler's study (2015) that a Chemistry Meeting often takes place between a potential new client and the agency is an important one and needs to be captured within the pre-relationship stage and the client/ad agency life cycle framework .

Furthermore, the current literature provides limited knowledge of the nature and role of Request for information (RFI) and Credentials 'Creds' meetings (IPA). This is disappointing given these are seen to be important aspects of the pre-relationship stage and warrant further attention in the literature. The IPA (2009) suggests that completing a RFI can take agencies a considerable length of time and have developed a template for agencies and clients to use in an attempt to simplify the process and reduce the time spent on completing requests. The template which was developed in association with the other main industry bodies including ISBA, IPA, DMA, MCCA and PRCA provides a standard template for the agencies to respond to requests from prospective clients (IPA, 2009). In addition to identifying the key information areas for agencies, the RFI identifies the need for clients to 
provide some background on their communications needs. Information such as why they are reviewing the account, objectives, scope of work, territories, conflicts, budgets and timings is suggested. The industry template suggests this is a significant part of the pre-relationship stage and hence should be recognised within the overall client/ad agency life cycle.

Credentials or 'creds' meetings should also be recognised within the pre-relationship stage. While the current literature does not provide an adequate explanation of this important stage, Fill $(2013$, p.216) argues, "This is a crucial stage in the process, as it is now that the agency is evaluated for its degree of fit with the client's expectations and requirements". As this is the stage when the client visits the short-list of agencies and leads to the decision as to which agencies should be invited to pitch for their business this is a key stage in the prerelationship stage.

While it is important to capture these stages within a client/ad agency life cycle framework (see Figure 1), it is also worth noting the paucity of literature in this area and the need for further investigation as to the nature of these aspects in the pre-relationship stage. In particular we have limited understanding of the role of intermediaries. Tylee (2013) identifies that about 400 plus pitches take place in the UK every year and of these between 35 to 40 percent are managed by intermediaries. Their role within the pre-relationship stage would provide a valuable insight into client/ad agency relationships.

\section{Early relationship stage}

While some client/ad agency life cycle frameworks recognise a development stage within the relationship (Fam \& Waller, 2008; Halinen, 1996; Wackman et al, 1986; Waller, 2004) the nature of this stage within the client/ad agency relationship is less understood. 
Since it is understood that the relationship has already progressed beyond the Creds meeting and Chemistry Meeting the relationship is in the early stage. This stage includes the Tissue sessions and Pitch presentation. See Figure 1.

Tissue sessions were first identified in the literature by Turnbull and Wheeler (2015) who identified this as a meeting held early on in the creative process to review initial creative ideas and their study explains from one account manager's perspective what takes place at such meetings, "we put up a load of solutions on the wall of their meeting room, down in their offices, and we took the creatives with us and we took our Creative Director, and we very loosely talked through ... 'your brief is making us think about these kinds of areas'” (p.11). Tissue sessions are held both with existing clients and prospective new business clients to get initial feedback and validation on creative ideas. Again this is an important meeting between the client and agency and needs to be recognised as part of the early relationship stage.

The Pitch presentation should also be recognised in any client/ad agency life cycle framework and within the early relationship stage. Although Smith (2013) reports that the number of pitches decreased by $10 \%$ there were still 438 account reviews and invitations to pitch in the UK. The literature on the Pitch presentation itself is limited. Indeed Moeran (2005) provides one of the few studies on the Pitch process and reveals the significance of the presentation. In particular Moeran (2005) highlights the dramatic nature of the pitch presentation itself and reveals the importance clients attribute to creativity and agency people. Fill (2013) similarly describes the nature of the pitch and identifies that the pitch requires the agency to make strategic and creative proposals to the client and as a result of this the account is awarded to the most suitable proposal made. Hence, the pitch presentation is a key part of the early relationship stage between the client and the agency and needs greater recognition for its role in the client/ad agency life cycle. 
The industry recognises the significance of the pitch during the early relationship stage of relationship development. Although much of the recent debate in the industry press has been concerned with the problematic nature of the process itself and poor practice (Magee, 2015) the pitch continues to be a main method of selecting or re-engaging an agency to manage its account.

Industry bodies suggest that selecting an agency and the pitch process itself has become an area of concern with the ISBA and Institute of Practitioners in Advertising (IPA) holding a 'Good Pitch Week' to address the problems (Chahal, 2013). There has been much discussion in the industry press in recent years over the unfair nature of the pitch process and cases where industry bodies have felt practices are poor. Spary (2015) for example reports on $A B$ InBev which led to The Marketing Agencies Association calling for agencies to boycott the pitch altogether. Phillips (2015) argues that the discontent with the pitch process has been ongoing for 17 years and suggests that to resolve the pitch debate, incumbent agencies should not be involved in a pitch. Phillips (2015) suggests that excluding the incumbent agency may make clients think more carefully before they call a pitch.

A key concern in the industry is the cost of pitches (IPA, 2014) and the length of time the pitch process can take, despite the role of intermediaries. Rogers (2014) highlights the example of the British Airways pitch which took 7 months. The British Airways pitch was seen to be both a costly and demoralising experience for the losing agencies (Rogers, 2014).The IPA (2009) suggests clients should also consider alternatives to the pitch such as workshops or trial projects. They argue the benefits of a trial project are that it allows the client to experience working with the agency on a 'live project' and enables the agency to try out an alternative to their incumbent agency without damaging their existing agency relationship. The industry body also suggests workshops as an alternative which allow the agency and client to experience working together (IPA 2009). Despite this however, the pitch is still the preferred route by many clients. 
The industry debate surrounding pitch practices warrant further exploration and future studies could examine some of the issues raised.

\section{Transition Stage}

This is seen by practitioners to be a key stage in the client/ad agency relationship and has been the subject of much recent discussion in the industry (IPA, 2014). Until now however it has not been recognised in the literature.

The IPA recognises the importance of the transition stage in client/ad agency relationships and argues the need, "to recognise it as distinct and different, and agree specific procedures, practices and payments for this time period" (IPA, 2014, p.24). The identification of this unique stage when the agency and client will be developing long term strategic plans as well as servicing the tactical communication needs of the client is a significant one. It is also acknowledged that this stage of the relationship will involve meetings with both the incumbent agency and meetings with the new client team (IPA, 2014). Hence the nature of work at this stage of the relationship is significantly different than at other stages within the relationship.

The IPA suggests this stage should last 100 days and outlines a 10, 30, 60 and 90 day guideline for the client and agency to work towards to ensure the transition stage is smooth. Called 'The First 100 Days Charter' (IPA, 2014) guidelines for what should take place within this Transition stage is outlined in Table 2. 
Table 2. The Transition Stage (adapted from the IPA/AAR Group cited in IPA 2014)

To be completed within:

\section{Suggested tasks to be}

completed:

\begin{tabular}{|c|c|}
\hline 10 Days & $\begin{array}{ll}\text { - } & \text { Confirm agency team } \\
\text { - } & \text { Identify key stakeholders } \\
\text { - } & \text { Identify reporting procedures } \\
\text { - } & \text { Set expectations for managing the relationship } \\
\text { - } & \text { Agree method of remuneration }\end{array}$ \\
\hline 30 Days & $\begin{array}{l}\text { - Introduction of agency team to key stakeholders } \\
\text { - } \quad \text { Agree method of communication and frequency of meetings } \\
\text { - } \quad \text { Agree briefing and approvals processes and responsibilities }\end{array}$ \\
\hline 60 Days & $\begin{array}{l}\text { - Finalise handover from incumbent, including all assets. } \\
\text { - Start to agree on KPIs and evaluation process } \\
\text { - Review relationship progression }\end{array}$ \\
\hline 90 Days & $\begin{array}{l}\text { - Review processes: briefing, approvals and sign-offs } \\
\text { - } \quad \text { Evaluate professional and personal behaviour } \\
\text { - } \text { Agree scope of work for 6-12 months and agency resources } \\
\text { needed } \\
\text { - Agree remuneration } \\
\text { - Agree KPls and performance incentives } \\
\text { Agree on regular relationship audit }\end{array}$ \\
\hline
\end{tabular}

The IPA (2014) suggest this is an important stage in the client/ad agency relationship and that after the Transition stage is complete clients and agency will be able to evaluate how well they are working together, identify gaps in knowledge or team members and have an agreement on remuneration. Since this is seen by the industry to be a distinct stage in the client/ad agency relationship this needs to be reflected in the client/ad agency life cycle framework. See Figure 1. 
The lack of empirical knowledge of this stage of the relationship warrants further investigation. In particular longitudinal studies would allow us to gain a greater understanding of the nature of this Transition stage.

\section{Development and Maintenance Stage}

Most client/ad agency life cycle frameworks recognise a Development and Maintenance stage (Fam \& Waller, 2008; Wackman et al, 1986; Waller, 2004).

The literature suggests the needs of the client changes during this stage and that although factors such as creativity were seen to be a central focus in the Pre-relationship stage, this diminishes once the relationship enters the Development and Maintenance stage (Henke, 1995; Wackman et al, 1986). Clients are seen to be more interested in the performance and service the agency provides (Henke, 1995; Palihawadana \& Barnes, 2005). This is surprising since it is during this Development and Maintenance stage of the client-ad agency relationship that most of the advertising creative development work is carried out (Turnbull \& Wheeler, 2015).

Another feature of this stage of the relationship recognised in the literature is the personal relationships which develop between the client and the agency. These relationships are seen to be an important factor in the maintenance of the relationship (Davies \& Prince, 2011; Crutchfield et al, 2003; Davidson \& Kapelianis, 1996; Durkin \& Lawlor, 2001; Halinen, 1996; Harris \& Taylor, 2003; Haytko, 2004; Kaynak, Kucukemiroglu, \& Odabasi, 1994; Moeran, 2005; Zolkiewski et al, 2008). Specifically, it is the personal relationship and the personal chemistry which develops between the agency account handler and the client representative that is seen as particularly significant (Crutchfield et al, 2003; Davies \& Palihawadana, 2006; Grant \& McLeod, 2007; Haytko, 2004). 
The literature recognises that the close personal relationships which develop between the account handler and the client representative provides a number of advantages, such as; satisfaction with process outcomes and maintenance of the inter-firm relationship (Halinen, 1996); commitment (Halinen, 1996); information exchange (Halinen, 1996); reduced uncertainty and reduced opportunism (Davies \& Palihawadana, 2006); resolution and avoidance of conflict (Halinen, 1996); sociable work environment (Halinen, 1996); increase collaboration and act as an exit barrier (Grant \& McLeod, 2007). Furthermore, a good relationship between the client and the agency is perceived to contribute towards the output of the agency (Haytko, 2004).

The literature identifies however that not all clients seek close relationships with the agency (Durkin \& Lawlor, 2001; Hill \& Johnson, 2004; Prendergast \& Shi, 2001; So, 2005). In particular the literature recognises that in contrast to advertising agencies' desires to develop close personal relationships with their clients (Murphy \& Maynard, 1996; So, 2005), not all clients seek close personal relationships with their advertising agencies (Prendergast \& Shi, 2001; Verbeke, 1988).

Studies have identified that as a result different relationship styles emerge (Halinen, 1996; Haytko, 2004; Hill \& Johnson, 2004). Scholars distinguish between 'partnership' and 'master-servant' styles in client-agency relationships (Hill \& Johnson, 2004) and 'vendor', 'partner' and 'surrogate manager' taxonomies (Haytko, 2004). The literature also distinguishes between the operational style of the personal relationships between the client and agency; 'strictly business', 'business friends' and 'highly personal' (Haytko, 2004). There is also recognition that different taxonomies of relationship interaction styles exist, with clients adopting either 'open', 'formal' or 'investment initiatives' in their approach to communication with the advertising agency (Halinen, 1996). 
The literature also highlights the conflict that occurs between the client and agency (Gambetti, Biraghi, Schultz, \& Graffigna, 2015). Studies highlight the tension that occurs between the client and agency and identify a number of factors that cause the conflict in the relationship (Murphy \& Maynard, 1996). Zolkiewski et al (2008) for example identify that factors such as lack of client knowledge and risk aversion are two of the main sources of conflict that result in tension between the client and agency. Furthermore, LaBahn and Kohli (1997) suggest indecisiveness is also a cause of tension between parties. While minor conflict is seen to be beneficial (LaBahn \& Kohli, 1997), persistent conflict between the client and agency however can have a negative impact on the creative output (LaBahn and Kohli, 1997; Zolkiewski et al., 2008). Additionally persistent tension in the relationship is likely to lead to cause client dissatisfaction (IPA, 2009).

As already discussed there is some variance in the length that the relationship between the agency and client may last. For some relationships this may be 100 years (Day, 2002), while for others this may be more reflective of the industry average which is less than 3 years (ISBA, 2013).

While the literature has examined this aspect of client/ad agency relationships extensively there is scope to explore the evaluation of relationships and expectation management during this stage. For example we have limited knowledge of how KPIs are evaluated and the nature of review audits. These would be a fruitful area for future research.

\section{Dissatisfaction Stage}

Most client/ad agency life cycle frameworks see 'termination' as the final stage in the relationship process between clients and their agencies (Wackman et al, 1986; Waller, 2004). 
However while the industry press acknowledges clients can be dissatisfied with the agency performance and even call a pitch, it is also noted that in many cases they remain with the incumbent agency (Hammersley, 2012; Nettleton, 2008). Hammersley (2012) suggests that industry sources indicate that 20 per cent of pitches since 2011 have been won by the incumbent agency. This suggests that that while there may be a stage of dissatisfaction within the relationship, the partnership is not always terminated. In cases where a pitch is called the incumbent agency may win the pitch and retain the business and so the relationship continues. Industry sources highlight how Toshiba usually asks the incumbent agency to repitch for their account and include agencies on the shortlist whom they have worked with before (Anon, 2014) .

Furthermore, while most client/ad agency life cycle frameworks suggest that the relationship ends the industry literature suggests that some clients do return to previous agencies to work with them in the future and therefore this needs to be considered in any life cycle framework. Hence the client/ad agency life cycle framework suggested identifies a stage of Dissatisfaction followed by either a Pitch or Exit from current agreement. See Figure 1.

The current literature on agency termination recognises that ending relationships with advertising agencies is not difficult (Duhan \& Sandvik, 2009) a number of switching costs for clients have been identified (Davies \& Prince, 2010, 2011). For agencies there is the obvious loss of revenues and the potential impact on other agency accounts (Kulkarni et al, 2003) and for clients, there is the loss of time searching for and developing a relationship with a new agency (Fam \& Waller, 2008; Ghosh \& Taylor, 1999). Studies suggest that it takes clients an average of seven and a half months to appoint and have an operational working relationship with a new agency in place (Duhan \& Sandvik, 2009). This affords their competitors a significant opportunity in the market. In addition the literature suggests that a client's market share and market value may be negatively affected by changes in agency 
relationships (Kulkarni et al, 2003; Mathur \& Mathur,1996). Therefore, whilst terminating agency relationships may be easy for the client, there are switching costs involved.

Several studies have examined the reasons for the dissolution of client-ad agency relationships (Bennett, 1999; Durden et al, 1997; Ghosh \& Taylor, 1999; Michell, Cataquet \& Hague, 1992; Michell \& Sanders, 1995). The literature identifies that dissatisfaction with agency performance is the main reason that clients chose to terminate relationships (Durden et al, 1997; Ghosh \& Taylor, 1999; Henke, 1995; La Bahn \& Kohli, 1997). The literature primarily attributes the client's dissatisfaction with the agency's creative performance as the main cause of relationship termination (Bennett, 1999; Durden et al, 1997; Halinen, 1996; Helgesen, 1994). The relationship is not ended however purely because of one poor creative assignment, but rather a combination of factors which lead to relationship decline (Halinen, 1996).

Whilst creative work appears to be a significant factor in the termination decision, scholars also suggest that other factors contribute towards the decision, such as; the agencies inability to contribute to income (Bennett, 1999; Ghosh \& Taylor, 1999), results of the advertising campaign (Michell \& Sanders,1995), changes to agency personnel (Durden et al, 1997; Durkin \& Lawlor, 2001; Ghosh \& Taylor, 1999) and agency service (Durden et al, 1997; Ghosh \& Taylor, 1999).

The IPA suggests there are five main factors that cause client dissatisfaction. These are seen to be; poor performance, financial issues, lack of agency pro-activity, chemistry problems and breakdown of trust (IPA, 2009).

While there have been a number of studies in the past examining the causes for client dissatisfaction, there has been less consideration given to agency dissatisfaction in the relationship and this would be a fruitful area for further examination. 
This represents the stage when the current agreement between the client and agency is completed. This may be because the client decides to move the account to another agency, move the advertising in-house or in some cases because the incumbent declines to re-pitch for the business.

Part of this stage involves the transition from the incumbent agency to the new agency. As identified in Table 2 the incumbent agency is involved in handing over assets to the new agency during this stage. This will require liaison with the new agency and client over transfer of materials and information. Since it has been identified that clients and agencies may work together in the future the relationship is not completely ended or terminated as previous frameworks suggest. This stage therefore represents an exit from the current agreement rather than 'termination' of the relationship.

The literature provides little explanation of the relationship after the client exits an agency partnership. The extent to which the personal relationship between client and agency individuals is maintained would a worthwhile topic for future research. 


\section{Figure 1: The client/ad agency life cycle framework}

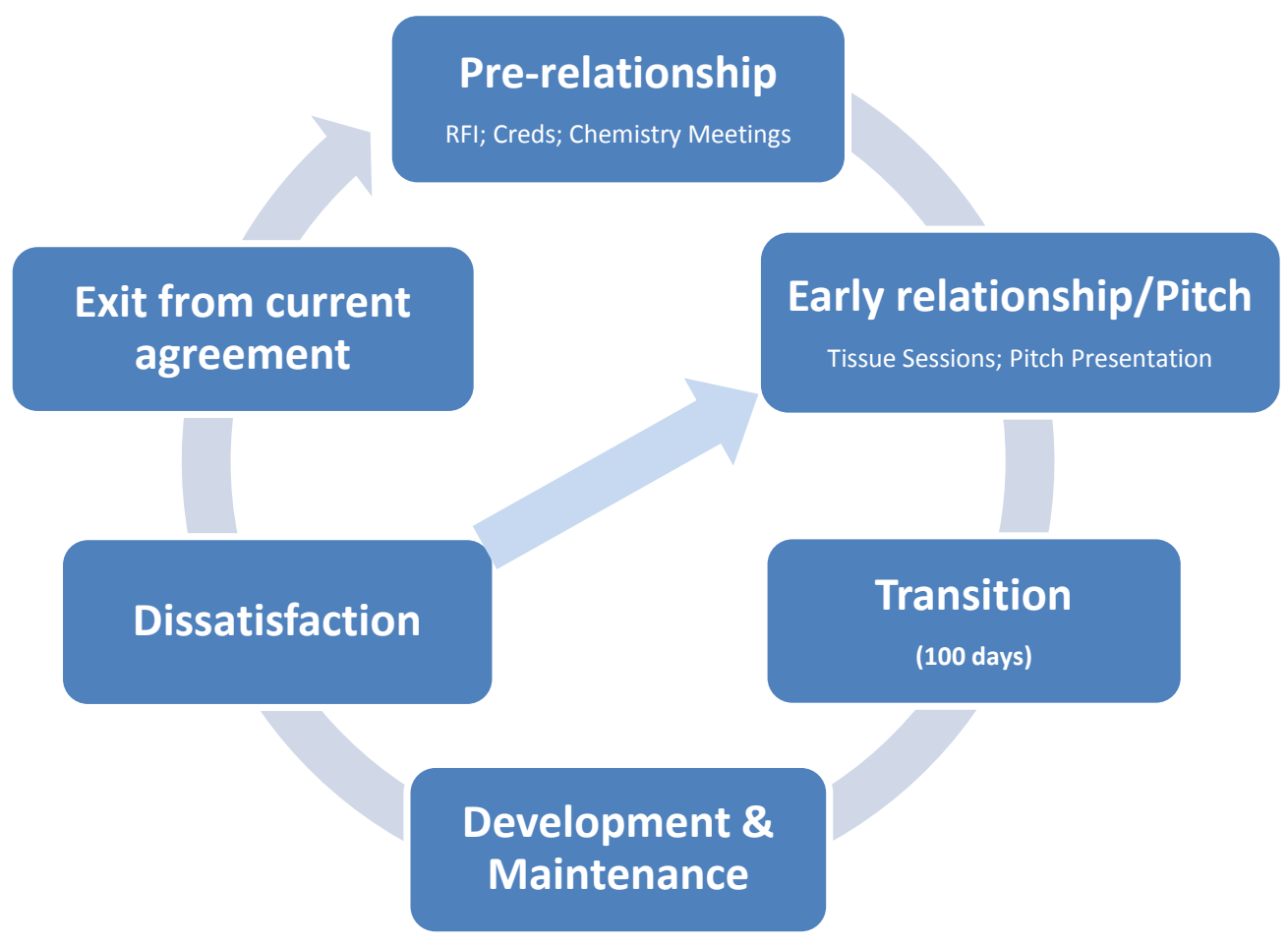

\section{Discussion and directions for future research}

The paper provides a new framework of the client/ad agency life cycle for further examination and research. Five different stages through which the client/ad agency relationship develop have been identified: Pre-relationship, Early relationship/Pitch, Transition, Development and Maintenance, and Dissatisfaction. An important aspect of the framework is the notion that the relationship is seen not to terminate but be part of an ongoing relationship cycle. As suggested in the industry press, clients are seen to call a pitch or exit the current arrangement but often ask agencies they have worked with in the past to pitch for their business. Furthermore, the framework differentiates between the Pre- 
relationship and Early relationship/Pitch stage. The Pre-relationship stage identifies the nature of activities that take place during this phase including RFIs, Creds meetings and Chemistry Meetings. Similarly the Early relationship/ Pitch stage includes Tissue Sessions and the Pitch presentation. Another important contribution of the framework is the identification of the Transition stage where the client and agency work on 'The First 100 Days Charter' (IPA, 2014). The revised framework more accurately reflects current practice and sets the agenda for future research on client/ad agency relationships.

While the limitations of this paper need to be highlighted, particularly the conceptual nature of the framework offered, it does extend our understanding of the client/ad agency lifecycle. Furthermore the revised life cycle framework highlights a number of gaps in the current literature and identifies topics that are worthy of future research. Within each stage of the client/ad agency life cycle a number of research areas have been identified.

- Pre-relationship stage; exploration of the Credentials meeting and the role of Chemistry Meetings. The role of intermediaries and the influence on the selection decision.

- Early relationship/Pitch stage: the pitch process and reasons for dissatisfaction with current pitch practices.

- Transition stage: the transition process and evaluation of stages.

- Development and Maintenance: relationships evaluation, use of KPIs and relationship audits.

- Dissatisfaction: Causes of agency dissatisfaction in the relationship. 
- Exit from current agreement: Relationship after current arrangements are over and exploring how relationships are maintained when formal contracts have ended.

Furthermore, it would be beneficial to see a wider variety of methodological approaches used in research in this area. In particular, ethnographic, longitudinal and case study approaches are scant and future research using these methodological approaches would provide rich insights into the client/ad agency relationship stages and life cycle. In addition further empirical research from different settings would be particularly welcome. For example International field settings would be of particular interest. Different agency settings would also extend our current knowledge in this area and it would be beneficial to see more studies undertaken with small and medium sized agencies, as well as with specialist and digital agencies in the future.

Finally future research could address other stakeholder's perspectives of current client/ad agency relationships. Holding companies and industry bodies such as the IPA would provide a more holistic understanding of the nature of the individual relationship stages and relationship life cycles.

In conclusion, client/ad agency relationships have evolved and academic research needs to keep pace with the changes that have taken place. New relationship stages and methods of working are in evidence and yet there is limited empirical knowledge of what takes place within these stage or why. This domain offers plenty of opportunities for future research and researchers are encouraged to explore these further. 


\section{References}

Anon (2014). Long live the pitch. BrandRepublic, 20 March 14. Retrieved from http://www.brandrepublic.com/article/1285584/long-live-pitch.

Bennett, R. (1999). Agency termination decisions by small to medium-sized charitable organizations. Journal of Marketing Communications, 5(3), 131-142.

Chahal, M. 2013. Pitches under the spotlight. Marketing Week. 6th November.

Crutchfield, T.N., Spake, D.F., D'Souza, G. \& Morgan, R.M. (2003). "Birds of a feather flock together": Strategic implications for advertising agencies. Journal of Advertising Research, 43(4), 361-369.

Davidson, S. \& Kapelianis, D. (1996). Towards an organizational theory of advertising: Agency-client relationships in South Africa. International Journal of Advertising, 15, 48-60.

Davies, M.A.P. \& Palihawadana, D. (2006). Developing a model of tolerance in client-agency relationships in advertising. International Journal of Advertising, 25(3), 381-407.

Davies, M. \& Prince, M. (2010). Advertising Agency Compensation, Client Evaluation and Switching costs: An Extension of Agency Theory. Journal of Current Issues and Research in Advertising, 32(1), 13-31.

Davies, M.A.P. \& Prince, M. (2011). Switching Costs and Ad Agency-Client Relationship Longevity: An Exploratory Study. Services Marketing Quarterly, 32(2), 146-159. 
Day, D (2002). THE FIRST 100 YEARS OF JWT \&amp; UNILEVER 1902-2002: Private View 1960s. BrandRepublic, 22 November. Retrieved from http://www.brandrepublic.com/article/164922/first-100-years-jwt--amp-unilever-1902-2002private-view-1960s.

Duhan, D. F. \& Sandvik, K. (2009). Outcomes of advertiser-agency relationships. The form and role of cooperation. International Journal of Advertising, 28(5), 881-919.

Durden, G., Orsman, T. \& Michell, P. C. N. (1997). Commonalities in the reasons for switching advertising agencies: Corroboratory evidence from New Zealand. International Journal of Advertising, 16, 62-69.

Durkin, M. \& Lawlor, M. (2001). The implications of the internet on advertising agency-client relationship. The Services Industries Journal, 21(2), 175-190.

Dwyer, F. R., Schurr, P. H. \& Oh, S. (1987). Developing Buyer-Seller Relationships. Journal of Marketing, 51(2), 11-27.

Fam, K .S. \& Waller, D.S. (1999). Factors in Winning Accounts: The views of Agency Account Directors in New Zealand. Journal of Advertising Research, 39(3), 21-32.

Fam, K .S. \& Waller, D.S. (2008). Agency-client relationship factors across life-cycle stages. Journal of Relationship Marketing, 7(2), 217-236.

Fill, C. (2013). Marketing Communications. brands, experiences and participation. $6^{\text {th }}$ ed. London: Pearson. 
Ford, D. (1980). The development of buyer-seller relationships in Industrial markets . European Journal of Marketing, 14(5/6), 339-353.

Gambetti, R., Biraghi, S., Schultz, D. E., \& Graffigna, G. (2015). Brand wars: consumerbrand engagement beyond client-agency fights. Journal of Strategic Marketing, (ahead-ofprint), 1-14.

Ghosh, B.C. \& Taylor, D. (1999). Switching agency - a cross-country analysis. Marketing Intelligence \& Planning, 17(3), 140-146.

Grant, I. \& McLeod, C. (2007). Advertising agency planning - conceptualising network relationships. Journal of Marketing Management, 23(5), 425-442.

Grönroos, C. (1980). Designing a Long Range Marketing Strategy for Services. Long Range Planning, 13(2), 36-42.

Halinen, A. (1996). Relationship Marketing in Professional Services. A study of agency-client dynamics in the advertising sector. Florence, KY, USA: Routledge

Hammersley, P. (2012). Is it worth an incumbent repitching? BrandRepublic. Retrieved from http://www.brandrepublic.com/article/1131032/worth-incumbent-repitching.

Harris, J. \& Taylor, K. A. (2003). The case for greater agency involvement in strategic partnerships. Journal of Advertising Research, 43(4), 346-352.

Haytko, D.L. (2004). Firm-to-firm and interpersonal relationships: perspectives from advertising agency account managers. Journal of the Academy of Marketing Science, 32(3), 312-328. 
Helgesen, T. (1994). Advertising awards and advertising agency performance criteria. Journal of Advertising Research, 34, 43-43.

Henke, L.L. (1995). A longitudinal analysis of the ad agency-client relationship: Predictors of an agency switch. Journal of Advertising Research, 35(2), 24-30.

Hill, R. \& Johnson, L.W. (2004). Understanding creative service: a qualitative study of the advertising problem delineation, communication and response (APDCR) process. International Journal of Advertising, 23(3), 285-307.

IPA (2014). A is for Alliances. IPA. Retrieved from http://www.ipa.co.uk/document/a-is-foralliances

IPA (2009). Finding an Agency full version. IPA. Retrieved from http://www.ipa.co.uk/Document/finding-an-agency-full-version.

IPA (2009). Request for Information (RFI) template. IPA. Retrieved from http://www.ipa.co.uk/document/request-for-information-rfi-template.

ISBA (2013). The Good Pitch. Best Practice for clients \& agencies. ISBA. Retrieved from http://www.thegoodpitch.com/home/background-research.

Jansen van Rensberg, M., Venter, P. \& Strydom, J.W. (2010). Approaches taken by South African advertisers to select and appoint advertising agencies. South African Business Review, 14(1), 1-26. 
Johanson, J. \& Mattsson, L.G. (1987). Interorganizational Relations in Industrial Systems: A Network Approach Compared with the Transaction-Cost Approach. International Studies of Management and Orientation, 17(1), 34-48.

Kaynak, E., Kucukemiroglu, O, \& Odabasi, Y. (1994). Advertising agency/client relationships in an advanced developing country. European Journal of Marketing, 28(1), 35-55.

Koslow, S., Sasser, S.L. \& Riordan, E.A. (2006) Do marketers get the advertising they need or the advertising they deserve? Agency views of how clients influence creativity. Journal of Advertising, 35(3), 81-101.

Kulkarni, M.S., Vora, P.P. \& Brown, T.A. (2003). Firing Advertising Agencies. Possible reasons and managerial implications. Journal of Advertising, 32(3), 77-86.

LaBahn, D.W. \& Kohli, C. (1997). Maintaining client commitment in advertising agency-client relationships. Industrial Marketing Management, 26(6), 497-508.

Magee, K. (2015). IPA slams Heinz pitch process and 'the long hand of procurement'. BrandRepublic, 22 June. Retrieved from http://www.brandrepublic.com/article/1352420/ipa-slams-heinz-pitch-process-the-long-handprocurement.

Mathur, L. K. \& Mathur, I. (1996). Is value associated with initiating new advertising agencyclient relations?. Journal of Advertising, 25(3), 1-12.

Michell, P. C., Cataquet, H., \& Hague, S. (1992). Establishing the causes of disaffection in agency-client relations. Journal of Advertising Research, 32(2), 41-48. 
Michell, P.C. \& Sanders, N.H. (1995). Loyalty in agency-client relations: the impact of the organisational context. Journal of Advertising Research, 35(2), 9-22.

Moeran, B. (2005). Tricks of the trade: The performance and interpretation of Authenticity. Journal of Management Studies, 42(5), 901-922.

Murphy, P. \& Maynard, M. (1996). Using judgement profiles to compare advertising agencies' and clients' campaign values. Journal of Advertising Research, 36(2), 19-27.

Na, W., Marshall, R. \& Son, Y. (2003). How businesses buy advertising agency services: A way to segment advertising agencies' markets?. Journal of Advertising Research, 43(1), 8695.

Nettleton, K. (2008). BrandRepublic Why do clients stick with incumbents? 15 August. Retrieved from http://www.brandrepublic.com/search/articles?keywords=Why\%20do\%20clients\%20stick\%2 Owith\%20incumbents\%3F\&headlinesOnly=False

Palihawadana, D. \& Barnes, B. R. (2005). Investigating agency-client relationships in the Polish advertising industry. International Journal of Advertising, 24(4), 487-504.

Phillips, P. (2015). Pitch perfect. BrandRepublic,19 March. Retrieved from http://www.brandrepublic.com/article/1338696/pitch-perfect.

Prendergast, G. \& Shi, Y. (2001). Client perceptions of advertising and advertising agencies: a China study. Journal of Marketing Communications, 7, (2), 47-63 
Rogers, D. (2014) Lessons learned from BA's marathon creative review. BrandRepublic, 20 March. Retrieved from http://www.brandrepublic.com/article/1286069/lessons-learned-bas$\underline{\text { marathon-creative-review. }}$

Shaw, P. (2014). 10 rules for TV strategy. Admap, December 2014. Retrieved from http://www.warc.com/Content/ContentViewer.aspx?MasterContentRef=ef698805-754b$\underline{4937-9058-6 a 2 b 4461 b 1 b 6 \& q=10+\text { rules }+ \text { for }+T V+\text { strategy\&CID=A103326\&PUB=ADMAP }}$

Smith, C. (2013). Four tips for pitching a new client. The Guardian, 5 April. Retrieved from http://www.theguardian.com/media-network/2013/apr/05/four-tips-pitching-client-advertising .

So, S.L.M. (2005). What matters most in advertising agency performance to clients: Implications and issues on their relationship in Hong Kong. Journal of Current Issues and Research in Advertising, 27(2), 83-98.

Spanier, G. (2010). What's the secret of a long-term relationship in advertising? London Evening Standard, 19 July. Retrieved from http://www.standard.co.uk/business/markets/whats-the-secret-of-a-longterm-relationship-inadvertising-6493416.html?origin=internalSearch.

Spary, S. (2015). The industry needs to adopt an open dialogue about 'despicable' pitch practice. BrandRepublic, 28 April. Retrieved from

http://www.brandrepublic.com/article/1344783/industry-needs-adopt-open-dialoguedespicable-pitch-practice

Turnbull, S. (2014),"Why are client/agency relations shortening?" Campaign Middle East, 1 (123). p. 20. 
Turnbull, S., \& Wheeler, C. (2015). The advertising creative process: A study of UK agencies. Journal of Marketing Communications, (ahead-of-print), 1-19.

Turnbull, S., \& Wheeler, C. (2014). Exploring advertiser's expectations of advertising agency services. Journal of Marketing Communications, (ahead-of-print), 1-15.

Tylee, J, (2013). Adland's marriage brokers. BrandRepublic,10 October 13. Retrieved from http://www.brandrepublic.com/article/1215380/adlands-marriage-brokers

Verbeke, W. (1988). Developing an advertising agency-client relationship in the Netherlands. Journal of Advertising Research, 28(6), 19-27

Waller, D.S. (2004). Developing an account-management life cycle for advertising agencyclient relationships. Marketing Intelligence \& Planning, 22(1), 95-112.

Wilson, D.T. (1995). An Integrated Model of Buyer-Seller Relationships. Journal of the Academy of Marketing Science, 23(4), 335-345.

Zolkiewski, J. Burton, J. \& Stratoudaki, S. (2008). The delicate power balance in advertising agency-client relationships: partnership or battleground? The case of the Greek advertising market. Journal of Consumer Behaviour, 7(4), 315-332. 